\title{
HOUSING CHOICE STRUCTURE: EXAMPLES OF TWO DIFFERENT-SIZE CITIES FROM TURKEY
}

\author{
Elif ALKAY a,* \\ ${ }^{a}$ Department of Urban and Regional Planning, Urban and Regional Planning ITU, Istanbul Technical \\ Univarsity, Taskisla, Istanbul 34437, Turkey
}

Received 14 August 2013; accepted 20 February 2014

\begin{abstract}
The distribution pattern of housing in any urban area will be extremely diverse and heterogeneous. The shape of this pattern depends on intrinsic properties of the housing units themselves as well as on accessibility, environmental quality and the capacity and quality of previously constructed housing stock. How do households make their choices and distribute themselves among such diverse housing areas? The aim of this investigation is to put the factors that could define the choice structure of households by focusing on two different-size cities in Turkey: the Istanbul Metropolitan Area (IMA), where the housing choice is expected to dependent upon economic behavior of households, and Bandirma (BND), a medium-size city, where the housing market is relatively weaker and the choice structure is expected to dependent upon the limited opportunities of supply. The investigation results show that households' socio-economic characteristics dominate the choice structure in the IMA parallel to the expectation. Housing properties have a more notable impact on the choice structure in BND that acknowledged the relative limitation of the housing market.
\end{abstract}

KEYWORDS: Housing; Housing choice; Modeling; Bandırma; Istanbul

\section{INTRODUCTION}

Households' residential choice is one of the most striking research areas in the social sciences. In making choices, where alternatives are heterogeneous, consumers presumably sample from a large number of available dwellings. They evaluate the physical characteristics of these dwellings, the neighborhoods in which they are located, and the public services provided to them. On the basis of these evaluations and the prices at which dwellings are offered, the consumer ultimately chooses one dwelling out of the sampled alternatives (Quigley 1985).

The residential choice of households are affected by several factors: the market structure by itself; external factors such as political circumstances, economic policies, social networks and relations; the housing and land supply policies of both central and local governments; and internal factors such as households' well-being and expectations.

\footnotetext{
* Corresponding author. E-mail: alkayel@itu.edu.tr
}

All of those influence economic behavior of households that consequences of the behavior can be observed in housing prices, quantities exchanged and location and choice of space.

Housing markets are local and diverse. Therefore, the choice structure of households would be expected to vary. What is obvious in one city is not necessarily obvious in another. So, it has been natural to extend choice structure to a wide variety of places. The combined economic and sociodemographic literature on housing choice has provided an explanation of housing behavior in Western cities basically. This study aims to analyze the households' residential choice structure by focusing on two different-size cities from Turkey: the Istanbul Metropolitan Area (IMA) and Bandirma (BND). Investigation focuses on the parameters of residential choice on these two different sizes of urban area. What is the residential choice pattern of residents in a metropolitan area and a medium size city? This is the basic research question that investigated in the research. Results are expected 
to contribute a discussion whether the residential choices change structurally between a metropolitan area and a medium size city. Research would be an example for that rarely investigated medium-sized city.

Following the introduction, the research is organized into four sections. The second section provides the background, citing previous studies which discuss both external and internal factors that have important roles in the choice structures of households. The third section puts the panorama of the investigation period and general characteristics of the housing markets of the investigation areas. The data, the variables and the model structure is discussed in the third section. Estimation results are advanced and discussed in the fourth section. The last section offers concluding remarks.

\section{BACKGROUND AND PREVIOUS STUDIES}

Residential location modeling dates back to the 1960s. Alonso (1974) constructs the foundations for the economic analysis of residential location by applying von Thünen's key 'bid-rent' idea to this subject. The core of the model is a trade-off between access to the urban center and land. He emphasizes that an individual household merely wishes to maximize its satisfaction by owing and consuming the goods it likes and avoiding those it dislikes. Also, an individual will try to maximize his satisfaction within the constraints of his income. An individual equilibrium at a residential location will correspond to the opportunity which yields the individual greatest utility under his budget constraint (Alonso 1974). By following economic analysis, Muth (1969) applied budget constraint models while changing some of Alonso's assumptions. The equilibrium location is determined in Muth's model by the land-price and commuting-cost functions, where the marginal decrease in expenditures on housing is equal to the marginal increase in commuting costs for small changes in distance (Muth 1969).

Alternatively, Lowry (1964) uses spatial interaction principles in modeling residential location. He argues that the number of households in a definite area is a function of that definite area's accessibility to employment factors. Therefore, the pattern of residential location is described as a function of the spatial distribution of employment opportunities, constrained by the availability of land suitable for residential development. In his model, the journey to work and the availability of employment are basic principles that influence residential choice.

The availability and cost of public services also influence housing choice and demand. Each residential area is characterized by some range of public services that are available to residents at a zero price, and that are unavailable to nonresidents at any price (Hirsch 1968). Tiebout (1991) emphasizes that households would like to get the maximum benefit from their choices and that they prefer the highest accessibility to public places; therefore, the spatial distribution of public spaces has a direct impact on households' residential choice.

The strength of demand for housing is also responsive to the quality of its environment. Schnare and Struyk (1976) were the pioneers in emphasizing the importance of environmental quality and including it in residential choice modeling as a factor. There are physical characteristics (landscape, weather) and the characteristics of the people who live in the neighborhood (social environment) (Hirsch 1968; Megbolugbe et al. 1991). Moreover, local fiscal and public goods have a direct impact on the environmental quality of a neighborhood. Some studies investigate how these attract residents' choice, particularly; school quality is emphasized among key determinants of the choice (Bayoh et al. 2006).

Another principle that plays an important role in housing choice and demand is emphasized by Rossi (1955). He was the first to discuss the family life-cycle paradigm in residential choice. The paradigm defines a household's or a family's life as the whole of complex activities which are surrounded by social, economic and geographic forces. Any changes in the family structure would be a major reason for residential mobility. The ages of family members, the education level of the household and the income level of the family are major factors that have a striking impact on housing choice and demand. Any changes in one of these factors means a change in the benefit that the household gets from its current dwelling. Since households would like to continue to receive maximum benefit from their dwelling, they will tend to develop a new choice and demand pattern and choose another dwelling from which they could get the maximum benefit (Rossi 1955; Clark et al. 1984; Speare, Goldscheider 1987; Clark, Huang 2003; Knox, Pinch 2006).

Residential decision makers - the demand side - are open to influence by both global and local developments. Households can be characterized on a great variety of dimensions depending on their 
economic and social conditions; choice structure is dynamic and gradually affected by social changes (Clark, Dieleman 1996). Observable changes in the society such as changing life styles depending on national and international human mobility, increases in life expectancy due to medical developments along with the possible demographic impact of these increases, flexible working conditions due to changing production patterns and increasing time spent at home have an important role on the choice pattern (Pagliara, Wilson 2010; Friedrich, Piesch 2007; Rossi 2007).

Residential choice is also affected by macroeconomic and political conditions. International and national macroeconomic policies, growth rates and interest rates are some of indications that play an important role in households' residential choice (Magalhaes 2002; Maclennan 2007; Rossi 2007). Another importance of economic indicators is their impact on households' tenure-type choices. Research shows the importance of economic conditions in the move from renting to home owning. Financial support systems, interest rates, new housing supply and prices are correlated with macroeconomic conditions, and they either increase or decrease the possibility of moving from renting to home owning. It is emphasized that if new housing supply is high and interest rates and supply prices are low, the rate of change in tenure type from renting to home owning is high. This is understood to create an economic environment that encourages homeownership for low income groups in particular. In economic conditions where housing prices and interest rates are high, relatively high-income groups are observed to change their tenure type from renting to owning. Therefore, housing choice examination should consider macroeconomic conditions, housing market potentials and restrictions, and the housing policies of central and local governments (Clark, Dieleman 1996).

The supply side consists of both current housing stock and new supply. The main problem is that the volume of new supply is always less than the amount of current stock, and the current stock has became incapable of corresponding to changing profile of the society. Consequently, supply-side opportunities are generally limited and the nature and size of the stock of housing available limits choice (Clark, Dieleman 1996; Clapham 2002; Pagliara, Wilson 2010; Balchin et al. 2000). Another difficulty is its correspondence to continuous macro scale changes. For instance, the inflation, interest and tax rates, along with population increases due to migration, are some of the macroeconomic con- ditions to which the supply side must adapt itself in order to correspond to these continuous changes. Consequently, the supply side, much like the demand side, has a segmented and dynamic structure (Magalhaes 2002; Pagliara, Wilson 2010).

A segmented and dynamic structure of both demand and supply sides creates the main difficulty of modeling the housing market and determining the factors behind residential choice by households. There are several continuously evolving factors that have striking impacts on determining housing choice structure. This makes the housing choice process as a multicriteria decision process (Leishman 2003). Moreover, it emphasizes the necessity of evaluating each choice model contextually and be critical in generalizing the results (Pagliara, Wilson 2010).

\section{MODELING CHOICE}

\subsection{The panorama of the investigation period}

The choice structure of households is investigated by focusing on the last nine years period in particular because 2004 is accepted as the year of the boom of the construction sector which has been sustaining to grow remarkably since then; housing finance and credit interest rates are relatively lower; disposable income is relatively increased; macroeconomic indicators are relatively positive.

The big economic crisis in 2002 has been overcome by structural economic reforms in Turkey. Since 2004, the governing fundamentalist party has insisted on applying those inherited reforms and consequences are successful. Although periodical decreases have occurred in some years, the economic indicators positively changed between 2004 and 2011. Positive economic conditions have lead to an increase in housing consumption on the part of all households and stimulated the housing demand.

The increase in demand capacity is reflected by the net increase of the housing stock. The number of residential units awarded housing construction permits have increased from 161,920 to 823,060 from 2002 to 2010 (TUIK 2010). Of the total floor area of buildings awarded construction permits in $2011,62.4 \%$ is occupied by housing (TUIK 2012). The percentage share of housing in fixed capital investments is observed as $12.2 \%$ in 2012 (Türkiye Müteahhitler Birliği 2012). However, the difference between housing need and supply is still huge. According to GYODER (2011), the difference between total housing need according to the population and 
the number of residential units awarded housing construction permits was $74 \%$ in 2002 . Although the difference has decreased to $15.7 \%$ in 2007, it still remarks a huge difference (GYODER 2011).

Contrary to positive economic developments and developments in construction sector, housing policy side reflects weaknesses. Since 1963, nine development plans for five years period have been prepared in order to regulate economic growth in the country. Except the last one, all of them included housing as an important factor of development and they promised and discussed housing policies in order to solve the several problems. However, none of these policies are comprehensive. Developed policies do not go beyond supply-side and demand-side housing subsidies. They are incapable of linking housing investments to economic developments and land use policies. They have not taken a proactive approach by facilitating more efficient land use patterns so far. A stable and equitable housing finance system has not been ensured. A legal structure about mortgage was aimed and The Law: 5582 was approved in March 2007 (Resmi Gazete 2007). The aim of the law is to provide repayable credits to the housing consumers and to structure a housing finance system open to new developments. However, the law has criticized by emphasizing particular three points: (1) the enacted law is not constructed as a frame law; it is enacted by making new regulations or additions to the current several related laws, (2) although one of the main components of the mortgage system is the consumer side, the regulations do not consider the consumer side enough (3) a direct and responsible authority is not defined in order to execute the law (Kabatas 2007; Berberoğlu 2009; Can 2011). The problems have survived for low and moderate income households. The system that provides exceptional support to those groups has not been constructed. Alternative homeownership models that help extend homeownership among low and moderate income households have not been supported. Consequently, the choice structure is modeled in a positive economic environment that has not been working consistently with comprehensive housing policies.

\subsection{General characteristics of the housing market in the IMA and BND}

To discuss households' choice structure, the basic characteristics of local housing markets are needed to be understood. Different urban development processes and different economic structures have led to different market structures in these case areas.

In the IMA, housing market is spatially segmented (Alkay 2008; Keskin 2008). Consequently, the changes in the market values seem to greater in the metropolitan area (Koramaz, Dökmeci 2012). Physical planning, newly developed business areas, huge public investments on transportation in particular, privatization of public properties, urban transformation are among the basic factors that have formed the housing market since 2004. All those have introduced new complexities into the structure of the metropolitan housing market also. The congestion of the outer ring is substantial in last nine years specifically. Middle income population flow towards the new stock is remarkable. The sociological codes support such a flow as well. Housing that accepted as the most reliable and profitable investment tool stimulates suburbanization. The comprehensively designed new environments in the outer ring have distinguished those housing areas from the current stock on the basis of environmental and locational characteristics, as well as, have resulted in particular fractions of the middle income groups. However, the market is still tight for low-income groups. The instruments in order to providing adequate housing for lowincome groups and social accuracy of supply subsides are not responsive efficiently. The attempt in order to cover the housing demand of low-income a)

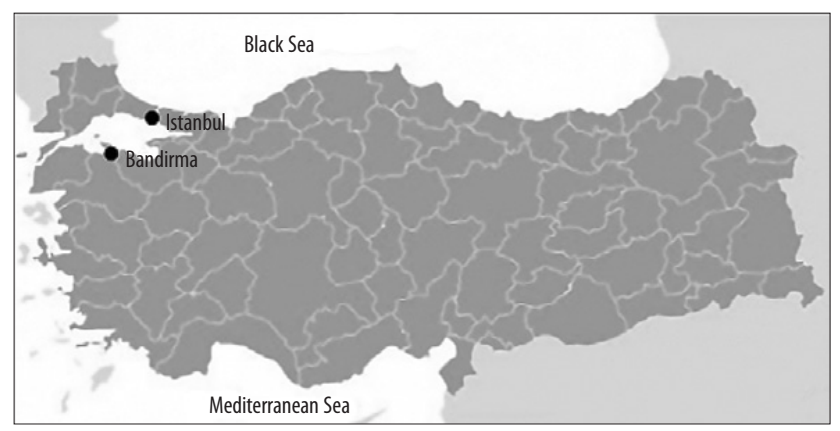

b)

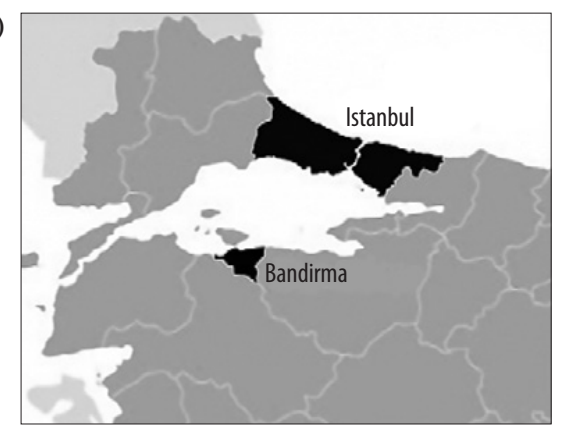

Fig. 1. The location of the IMA and BND in Turkey - in Marmara region (a, b) 
households is weak. Low income households have trapped in small housing areas: they tend to locate where property prices are the lowest in the city-at the periphery, also, locate in illegal housing areas distributed across the metropolitan area.

In order to have elastic supply of housing in growing urban areas, all parts of the supply chain including land market and urban planning must function well. In BND, the city land market is tight as a consequence of the limited supply of building land. The current application plan is incapable of developing policies in order to solve and regulate the land supply problem. Such a tight market has some consequences that impact on housing supply indirectly. Land prices across the city are high or the price of land slightly declines at distant from CBD (land price is high in long distance areas from the CBD depending on the limited supply, land price is high nearby CBD depending on the zoning restrictions and high competition among urban functions-residential areas are unable to compete with retail or office space in and around CBD). At any distance from the CBD, the value of housing gradient would tend to be steeper because of the greater relative importance of land as opposed to tendency that they tend to decline with distance from the CBD. Limitations on land supply have spatial consequences such as high density and inadequacy of urban facilities. The greater the price of residential land and hence the price of housing, the greater the intensity of residential land use. New supply is limited for several tastes as opposed to the metropolitan area. Supply is dominated by multi-unit structures, and there is little single-family housing supply. New supply targets basically to high income groups. It is strikingly limited for lowincome groups. Some deprived parts of the current stock have been occupied by low-income groups that basically stimulated filtering-down process in and around central areas. Therefore, residential segregation based on economic status is sharp and tending to be polarized in the city.

\subsection{Data}

The data set is a micro-level data and comes from two different sources. The first data source is a 'Household Research' survey that was conducted by the Istanbul Greater Municipality between 2005 and 2006. The survey sample is based on varying densities of housing areas. Sampling units are selected randomly for corresponding to these areas, and the sampling size is based on the population of these segments. The final survey of the first data set covered 3.862 households.
The second data source is another 'Household Research' survey that was conducted by Alkay and Kaya in 2010. The survey sample is based on varying housing stock areas across Bandirma. Construction year, construction type, housing type, story, and density are the primary characteristics used to define varying housing stocks. Sampling units are selected randomly for corresponding to these areas, and the sampling size is based on the population of these segments. The final survey of the second data set covered 789 households.

Both of the surveys have similar structures that could be classified into six main modules: (1) the socio-demographic structure of households, including factors such as age and family size; (2) the socio-economic structure of households, including income, employment status, car ownership and educational attainment; (3) housing characteristics such as room number, floor area, number of bathrooms; (4) the residential mobility pattern of households, including the location of the old dwelling and intention to move to a different housing area from the current one; (5) satisfaction with current housing and housing environment, including satisfaction with public places, green areas or accessibility to various facilities; (6) problems with housing and the housing environment such as traffic, scarcity of green areas or safety.

\subsection{Methodology}

In this study, two urban micro-models of housing choice are developed. Consumers' choice structures are estimated depending on the socio-economic characteristics of households, qualitative capacity of housing stock and case-area-specific characteristics. Five equations are estimated in each case: one of these is for the whole sample; the other four equations are estimated in order to reflect the household choice structures of comparable groups.

The relationship between income and housing decisions is indisputable for most households. Income is fundamental to explaining housing choice because it is the source of funds for homeowners' payments of mortgage principal and interest, property taxes, insurance and utilities (Megbolugbe et al. 1991). In order to investigate how attributes of residential choice vary among families of different income; the survey population stratified into groups of comparable income levels. Tenure (owning or renting) is often defined as the other important dimension of housing choice, thus, it is the other stratifying factor of comparable groups.

Consistently, households whose income levels are below / above the average; and home owners / 


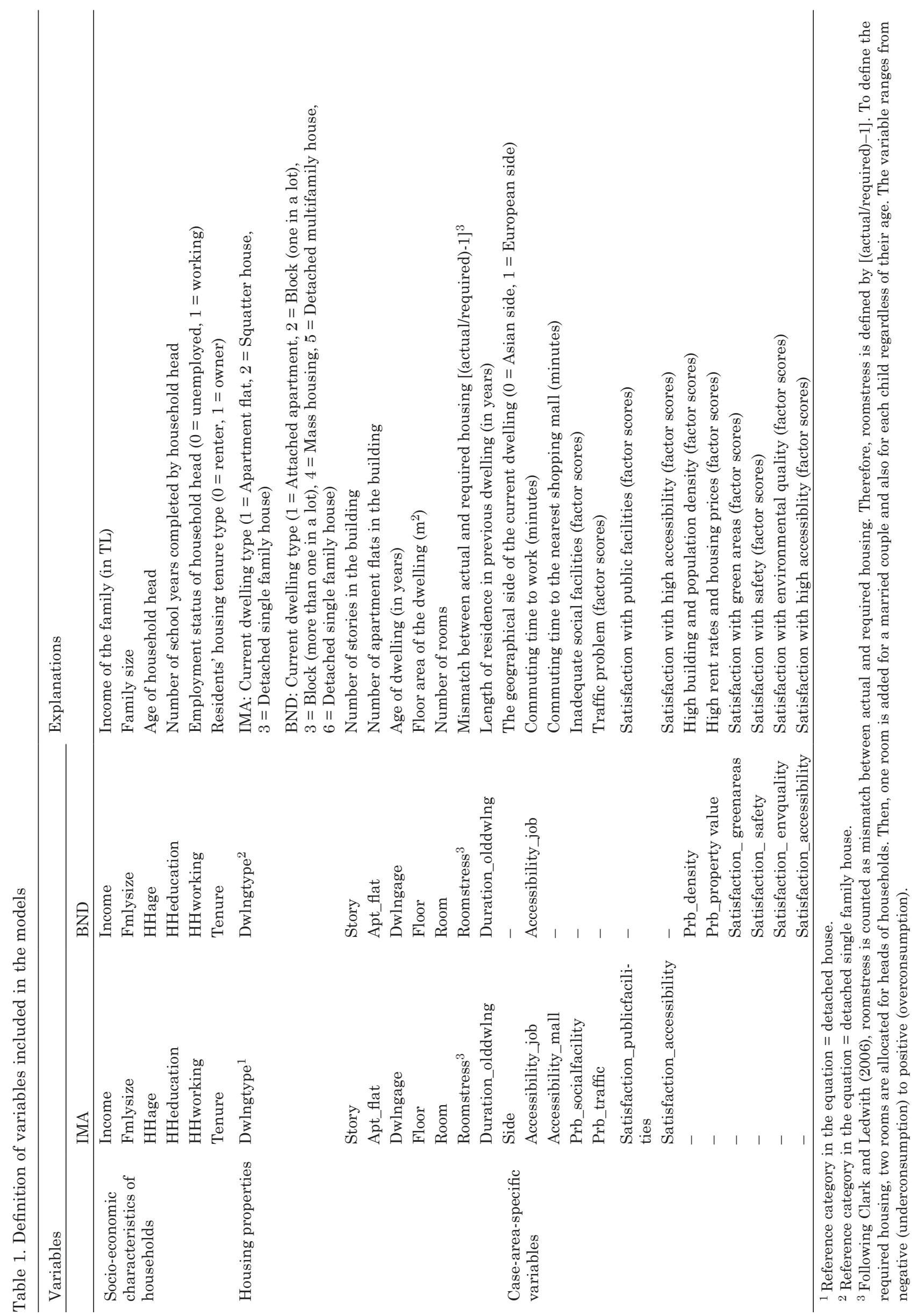


renters are comparable subgroups of the analysis. Households, whose income levels are below the average represent $48.6 \%$ of the whole sample, while the opposite represents $51.4 \%$ of the whole in the IMA. These rates are $65.4 \%$, and $34.6 \%$ in BND, respectively. While the average income in the metropolitan area is about half of the sample population, this share is about $2 / 3$ in the medium size city. Renters correspond to $33 \%$ and home owners correspond to $67 \%$ of the whole sample in the IMA. In BND, renters take $28.5 \%$ and homeowners $70.1 \%$ of the sample total. The share of the renters and home owners are parallel in two case areas.

\subsection{Variables and choice structure}

Variables that are expected to have an impact on housing choice structure are created into three groups: socio-economic characteristics of households, housing properties and case-area-specific variables. Variables created under the socio-eco- nomic characteristics of households and housing properties are parallel in two case areas. Since the urban area characteristics are different and problems and satisfaction with the housing environment could not be the same, case-area-specific variables are developed consistent to each case area. Case-area-specific variables reflect the particular properties of each study area considering the locational and environmental quality characteristics of housing areas. The full list of variables is provided in Table 1. The descriptive statistics of variables can be followed in Tables 2 and 3 .

The propensity to consume housing (for given income) is likely to vary with household characteristics. These overt socioeconomic characteristics of a household by define housing tastes and have a direct impact on consumption pattern. For instance, income level as well as higher occupational status and household life-cycle stage has stronger impact on housing type preferences. There might be a tendency for home ownership to increase with

Table 2. The descriptive statistics (IMA)

\begin{tabular}{|c|c|c|c|c|}
\hline \multicolumn{2}{|c|}{ Variables (IMA) } & Mean & St.d. & Frequency percent (\%) \\
\hline \multicolumn{2}{|l|}{ Income } & 1071.204 & 801.946 & \\
\hline \multicolumn{2}{|l|}{ Fmlysize } & 3.76 & 1.45 & \\
\hline \multicolumn{2}{|l|}{ HHage } & 45.28 & 13.087 & \\
\hline \multicolumn{2}{|l|}{ HHeducation } & 6.66 & 3.248 & \\
\hline \multirow[t]{2}{*}{ HHworking } & Unemployed & & & 34 \\
\hline & Working & & & 66 \\
\hline \multirow[t]{2}{*}{ Tenure } & Renter & & & 32.9 \\
\hline & Homeowner & & & 67 \\
\hline \multirow[t]{3}{*}{ Dwlngtype } & Apartment flat & & & 87.1 \\
\hline & Squatter house & & & 1.1 \\
\hline & Detached single family house & & & 12.8 \\
\hline \multicolumn{2}{|l|}{ Story } & 4.55 & 2.043 & \\
\hline \multicolumn{2}{|l|}{ Apt_flat } & 8.68 & 7.733 & \\
\hline \multicolumn{2}{|l|}{ Dwlngage } & 23.487 & 4.003 & \\
\hline \multicolumn{2}{|l|}{ Floor } & 96.43 & 25.584 & \\
\hline \multicolumn{2}{|l|}{ Room } & 3.31 & 0.783 & \\
\hline \multicolumn{2}{|l|}{ Roomstress } & 0.034 & 0.424 & \\
\hline \multirow[t]{2}{*}{ Side } & Asian & & & 16.1 \\
\hline & European & & & 47.1 \\
\hline \multicolumn{2}{|c|}{ Duration_olddwlng } & 11.99 & 10.146 & \\
\hline \multicolumn{2}{|c|}{ Accessibility_job } & 28.81 & 23.152 & \\
\hline \multicolumn{2}{|c|}{ Accessibility_mall } & 17.75 & 15.597 & \\
\hline \multicolumn{2}{|c|}{ Prb_socialfacility } & 0.000 & 1.000 & \\
\hline \multicolumn{2}{|l|}{ Prb_traffic } & 0.000 & 1.000 & \\
\hline \multicolumn{2}{|c|}{ Satisfaction_publicfacilities } & 0.000 & 1.000 & \\
\hline \multicolumn{2}{|c|}{ Satisfaction_accessibility } & 0.000 & 1.000 & \\
\hline
\end{tabular}


Table 3. The descriptive statistics (BND)

\begin{tabular}{|c|c|c|c|c|}
\hline \multicolumn{2}{|c|}{ Variables (BND) } & Mean & St.d. & Frequency percent (\%) \\
\hline \multicolumn{2}{|l|}{ Income } & 1180.51 & 786.932 & \\
\hline \multicolumn{2}{|l|}{ Fmlysize } & 3.23 & 1.344 & \\
\hline \multicolumn{2}{|l|}{ HHage } & 48.98 & 14.846 & \\
\hline \multicolumn{2}{|l|}{ HHeducation } & 7.46 & 3.875 & \\
\hline \multirow[t]{2}{*}{ HHworking } & Unemployed & & & 47.8 \\
\hline & Working & & & 51.8 \\
\hline \multirow[t]{2}{*}{ Tenure } & Renter & & & 28.4 \\
\hline & Homeowner & & & 69.9 \\
\hline \multirow[t]{6}{*}{ Dwlngtype } & Attached apartment & & & 56.5 \\
\hline & Block (one in a lot) & & & 10.5 \\
\hline & Block (more than one in a lot) & & & 11.5 \\
\hline & Mass housing & & & 2 \\
\hline & Detached multifamily house & & & 5.3 \\
\hline & Detached single family house & & & 13.5 \\
\hline \multicolumn{2}{|l|}{ Story } & 3.67 & 1.720 & \\
\hline \multicolumn{2}{|l|}{ Apt_flat } & 7.67 & 7.717 & \\
\hline \multicolumn{2}{|l|}{ Dwlngage } & 26.09 & 16.350 & \\
\hline \multicolumn{2}{|l|}{ Floor } & 96.42 & 28.691 & \\
\hline \multicolumn{2}{|l|}{ Room } & 3.44 & 0.775 & \\
\hline \multicolumn{2}{|l|}{ Roomstress } & 0.1763 & 0.493 & \\
\hline \multicolumn{2}{|c|}{ Duration_olddwlng } & 14.81 & 12.357 & \\
\hline \multicolumn{2}{|c|}{ Prb_density } & 0.000 & 1.000 & \\
\hline \multicolumn{2}{|c|}{ Prb_property value } & 0.000 & 1.000 & \\
\hline \multicolumn{2}{|c|}{ Satisfaction_greenareas } & 0.000 & 1.000 & \\
\hline \multicolumn{2}{|c|}{ Satisfaction_safety } & 0.000 & 1.000 & \\
\hline \multicolumn{2}{|c|}{ Satisfaction_envquality } & 0.000 & 1.000 & \\
\hline \multicolumn{2}{|c|}{ Satisfaction_accessibility } & 0.000 & 1.000 & \\
\hline
\end{tabular}

the age of the head of the household. The economic and social structure remarks some differences in case areas. The results would provide the possibilities for comparison of how those make difference on choice patterns of households. The household's length of stay is an important factor in its tenure decision (Megbolugbe et al. 1991). In order to investigate the relationship; the variable of duration is emerged.

As a product, housing has special characteristics that heterogeneity is a consequent important feature of this. A substantial variation among households in their preference for individual housing attributes is expected (Onaka, Clark 1983). The household choice of dwelling involves consideration of the physical characteristics of dwellings; the selection of a neighborhood by based on physical and social environments and the accessibility in particular (Quigley 1985). Housing variety is comparatively huge in metropolitan areas: mar- ket provides several supply alternatives for several tastes (Andersson et al. 2007). Conversely, the supply is limited both in quality and quantity in medium-sized cities. Thus, the impact of socioeconomic structure is expected to superior than housing properties on choice structure in the metropolitan area case. However, consequent of the limits of the market, the opposite is expected in the middle-size city.

Some of the variables are created specific to each case area. For instance, side is an IMA-specific variable. The Bosporus strait divides the metropolitan area into two main geographical parts, namely, the Asian and the European side, each of which reflects varying characteristics in population, density and urban land use. Therefore, the geographical parts of the metropolitan area have substantial importance in residential choice. Additionally, commuting time to the nearest shopping mall (accessibility_mall) is an IMA-specific varia- 
ble. As a medium-size city, BND has a traditionally developed downtown shopping area. The problems and satisfaction-related variables are also added in the group of the case-specific variables. They are created by applying factor analysis separately to each data set and identified for each case area as problems and satisfactions with physical environment. Location is another characteristic defines the stock's heterogeneity. The specification of location involves the distance from important locations (Megbolugbe et al. 1991; Smith et al. 1988). Therefore, location related variables are created by focusing on distance to working areas and satisfaction with high accessibility to several urban facilities in this study.

Housing choice can be examined based on economic approach and sociodemographic approach. The economic approach argues that households choose a certain type of housing to maximize utilities within a budget constraint. Sociodemographic approach argues that, in addition to economic factors, demographic characteristics of households and life-cycle events are significant factors affecting housing choice (Huang 2004). In the study, both the economic and sociodemographic approaches are combined in order to provide a good explanation of housing choice in two case areas.

In the choice procedure, the problem facing the household is choosing the single best unit for itself given the existing housing stock. Housing choice is a function of housing attributes including the residential environment and relative location, and individual or household characteristics. Preferences for a choice alternative are assumed to be independent of the existence of attributes of any other choice alternative that may be present in an individual choice set (Tu, Goldfinch 1996). Therefore, the estimation procedure attempts to identify the parameters that determine the maximum utility that a consumer will get under the budget constraint. Within this framework, a utility function is specified in the logarithmic form (1), which is estimated in the form of (2) (Wheaton 1974). In such a pattern, each consumer selects the unit where his utility is at a maximum.

$$
\begin{aligned}
& \mathrm{U}=\Sigma_{i} \alpha_{i} \log \mathrm{X}_{i}+\log \mathrm{Y}_{i}+\varepsilon, \\
& \log \mathrm{Y}_{i}=\mathrm{U}-\Sigma_{i} \alpha_{i} \log \mathrm{X}_{i}-\varepsilon
\end{aligned}
$$

$\mathrm{X}_{i}$ is an attributes vector which defines individual $i$ 's utility level (U) depending on socio-economic characteristics of households, housing properties and case-area-specific attributes. $\mathrm{Y}_{i}$ is the income of individual $i$. Income is the principal determinant of housing consumption. The previous researches have demonstrated that housing consumption varies at least in proportion to income (Muth 1969). Therefore, the dependent variable is gross monthly income and is explained by variables related to socio-economic characteristics of households, housing properties and case area-specific characteristics. Households of comparable income and tenure groups are approximately at a fixed utility level. Therefore, estimated functions of comparable stratified groups are in the same form.

\section{THE HOUSING CHOICE STRUCTURE OF HOUSEHOLDS IN THE IMA AND BND}

Tables 4 and 5 reports the estimated coefficients for the case area level variables from the logarithmic model specified in equation (2). Tolerance and VIF values do not point to multicollinearity; heterogeneity diagnosis shows that none of the equations displays a heteroscedastic pattern.

The results permit a number of observations and cautious conclusions. As it was emphasized, the housing choice structure is estimated for both whole samples and comparable groups stratified by income and tenure. Model results reflect that the impact of socio-economic characteristics of households, housing properties, and case-area-specific attributes are likely to differ between cities.

Socio-economic characteristics dominate the housing choice in the IMA. Although the variables of socio-economic characteristics that included in the equations are the same, their impact on the choice structure is different. While the household head education has the highest impact on housing choice structure for the metropolitan area as a whole and the homeowners and two different income groups, the family size impact on the choice structure is the highest for the renters. On the other hand, housing properties are not significantly more attractive than households' socio-economic characteristics by considering either their numbers or their impact on the choice structure. Except the side, any other site-specific-characteristics do significantly affect the households' choices in all equations. The impact of socio-economic characteristics on the choice structure is lesser than the impact of the housing properties and site-specific characteristics in the BND case. However, the difference between comparable groups is recognizable. For instance, none of the housing properties and site-specific characteristics has an impact on the choice structure of the low-income group. 
Table 4. The housing choice structure of households in the IMA

\begin{tabular}{|c|c|c|c|c|c|}
\hline & IMA & Income $<$ mean & Income $>$ mean & Home owner & Renter \\
\hline Constant & $\begin{array}{l}2,649 * \\
(46,636)\end{array}$ & $\begin{array}{l}3,190 * \\
(37,403)\end{array}$ & $\begin{array}{l}3,158^{*} \\
(56,738)\end{array}$ & $\begin{array}{l}2,869 * \\
(39,916)\end{array}$ & $\begin{array}{l}2,839 * \\
(23,616)\end{array}$ \\
\hline Fmlysize & $\begin{array}{l}0,280^{*} \\
(10,741)\end{array}$ & $\begin{array}{l}0,170 * \\
(4,684)\end{array}$ & $\begin{array}{l}0,229^{*} \\
(8,229)\end{array}$ & $\begin{array}{l}0,323^{*} \\
(10,095)\end{array}$ & $\begin{array}{l}0,504 * \\
(7,536)\end{array}$ \\
\hline HHage & $\begin{array}{l}0,301 * \\
(9,912)\end{array}$ & $\begin{array}{l}0,139 * \\
(4,325)\end{array}$ & $\begin{array}{l}0,104 * \\
(3,578)\end{array}$ & $\begin{array}{l}0,069^{*} \\
(2,109)\end{array}$ & $\begin{array}{l}0,329^{*} \\
(6,411)\end{array}$ \\
\hline HHeducation & $\begin{array}{l}0,378^{*} \\
(21,385)\end{array}$ & $\begin{array}{l}0,240 * \\
(8,908)\end{array}$ & $\begin{array}{l}0,240^{*} \\
(12,826)\end{array}$ & $\begin{array}{l}0,408^{*} \\
(19,447)\end{array}$ & $\begin{array}{l}0,367^{*} \\
(11,051)\end{array}$ \\
\hline HHworking (1) & $\begin{array}{l}-0,127 * \\
(-11,741)\end{array}$ & $\begin{array}{l}-0,281^{*} \\
(-9,287)\end{array}$ & $\begin{array}{l}-0,047^{*} \\
(-4,699)\end{array}$ & - & $\begin{array}{l}-0,141 * \\
(-7,413)\end{array}$ \\
\hline Roomstress & $\begin{array}{l}0,046 * \\
(2,058)\end{array}$ & $\begin{array}{l}0,083 * \\
(3,148)\end{array}$ & $\begin{array}{l}0,050 * \\
(2,430)\end{array}$ & - & $\begin{array}{l}0,174 * \\
(3,569)\end{array}$ \\
\hline Room & - & $\begin{array}{l}-0,124 * \\
(-2,145)\end{array}$ & - & - & $\begin{array}{l}-0,468^{*} \\
(-3,896)\end{array}$ \\
\hline Dwlngtype & $\begin{array}{l}-0,026 * \\
(-2,646)\end{array}$ & - & - & $\begin{array}{l}-0,041^{*} \\
(-5,322)\end{array}$ & - \\
\hline Apt_flat & $\begin{array}{l}0,341 * \\
(2,449)\end{array}$ & - & - & - & - \\
\hline Story & - & - & $\begin{array}{l}0,027 * * \\
(1,769)\end{array}$ & - & - \\
\hline Side (1) & $\begin{array}{l}0,124 * \\
(4,798)\end{array}$ & $\begin{array}{l}0,071^{*} \\
(2,312)\end{array}$ & $\begin{array}{l}0,062^{*} \\
(2,651)\end{array}$ & $\begin{array}{l}0,149 * \\
(4,739)\end{array}$ & $\begin{array}{l}0,137^{*} \\
(2,958)\end{array}$ \\
\hline Accessibility_mall & - & $\begin{array}{l}0,029 * * \\
(1,759)\end{array}$ & - & - & - \\
\hline $\mathrm{R}^{2}$ & ,493 &, 505 & ,348 &, 449 &, 502 \\
\hline ADJ.R ${ }^{2}$ & ,489 & ,483 & ,340 &, 445 & ,491 \\
\hline $\mathrm{F}$ & 124,917 & 23,339 & 42,648 & 104,784 & 44,122 \\
\hline
\end{tabular}

The significant variables are included in the table. Coefficients reflect standardized $B$ values. $t$ values are in parenthesis.

* Significant at $1 \%$ level.

** Significant at 5\% level.

The dominance of socio-economic characteristics of the households on the choice structure is parallel to the expectations in the IMA case. A percentage change in the education level is the most significantly impacting factor to the choice structure except for renters. The impact of socio-economic factors on the housing choice is limited with two variables - household head education and working status - in BND case. Working status of household head is included in equations in two different case areas. However, the impact of the variable is negative in the choice structure of households in the IMA contrary to BND. The interpretation of this opposite impact is difficult. In this case, the interpretation is based on job-accessibility for the IMA. Job-accessibility is the third most important reason of the residential mobility in the IMA (Alkay 2011). Considerably, it can be assumed that the current housing is the best unit in terms of its accessibility to job that unless the working status is not changed, it is preferred to stay. In BND case, the interpretation can be based on the economic context, and, active working status of the household head might have a possibility of sustaining income that the source of homeowners' payments of buying or renting a house.

IMA has a diverse housing stock. The spatial distribution and the varying physical and environmental quality of the stock supplies alternatives for diverse tastes; emerges relatively affordable housing prices to diverse income groups. Therefore, alternatives are several in order to evaluate tradeoffs. The less likely impact of housing properties on choice structure is reasonable. On the other side, as a medium size city, in BND, actual housing alternatives display less variation in the attribute levels. In another words, alternatives are likely similar in order to evaluate tradeoffs. 
Table 5. The housing choice structure of households in BND

\begin{tabular}{|c|c|c|c|c|c|}
\hline & BND & Income<mean & Income>mean & Home owner & Renter \\
\hline Constant & $\begin{array}{l}0,701^{*} \\
(12,680)\end{array}$ & $\begin{array}{l}0,934^{*} \\
(55,372)\end{array}$ & $\begin{array}{l}0,824^{*} \\
(12,446)\end{array}$ & $\begin{array}{l}0,601^{*} \\
(8,459)\end{array}$ & $\begin{array}{l}0,714^{*} \\
(12,035)\end{array}$ \\
\hline HHworking (1) & $\begin{array}{l}0,196^{*} \\
(3,980)\end{array}$ & $\begin{array}{l}0,390 * \\
(6,957)\end{array}$ & $\begin{array}{l}0,146^{* *} \\
(1,930)\end{array}$ & $\begin{array}{l}0,230 * \\
(3,851)\end{array}$ & $\begin{array}{l}0,189 * \\
(2,718)\end{array}$ \\
\hline HHeducation & $\begin{array}{l}0,272^{*} \\
(5,286)\end{array}$ & $\begin{array}{l}0,184^{*} \\
(3,285)\end{array}$ & & $\begin{array}{l}0,283^{*} \\
(4,603)\end{array}$ & $\begin{array}{l}0,215^{*} \\
(2,965)\end{array}$ \\
\hline Tenure (1) & - & $\begin{array}{l}0,156^{*} \\
(2,792)\end{array}$ & - & - & - \\
\hline Floor & $\begin{array}{l}0,279 * \\
(5,329)\end{array}$ & - & $\begin{array}{l}0,384^{*} \\
(5,046)\end{array}$ & $\begin{array}{l}0,308^{*} \\
(4,987)\end{array}$ & $\begin{array}{l}0,362^{*} \\
(5,029)\end{array}$ \\
\hline Apt_flat & $\begin{array}{l}0,139 * \\
(2,787)\end{array}$ & - & $\begin{array}{l}0,268 * \\
(3,595)\end{array}$ & $\begin{array}{l}0,121^{*} \\
(2,003)\end{array}$ & $\begin{array}{l}0,198^{*} \\
(2,842)\end{array}$ \\
\hline Dwlngage & $\begin{array}{l}-0,110^{*} \\
(-2,113)\end{array}$ & - & - & - & - \\
\hline Satisfaction_safety & $\begin{array}{l}-0,129^{*} \\
(-2,612)\end{array}$ & - & - & $\begin{array}{l}-0,179^{*} \\
(-3,006)\end{array}$ & - \\
\hline Prb_density & - & - & $\begin{array}{l}0,230^{*} \\
(2,983)\end{array}$ & - & - \\
\hline $\mathrm{R}^{2}$ & 0,360 & 0,232 & 0,307 & 0,393 & 0,333 \\
\hline ADJ $R^{2}$ & $0, .346$ & 0,223 & 0,285 & 0,376 & 0,314 \\
\hline $\mathrm{F}$ & 25,116 & 24,923 & 13,970 & 22,893 & 17,614 \\
\hline
\end{tabular}

The significant variables are included in the table. Coefficients reflect standardized $B$ values. $t$ values are in parenthesis.

* Significant at $1 \%$ level.

** Significant at $5 \%$ level.

Moreover, the supply side has some limitations either in the new supply or the current stock. The current stock in and around the central area is similar in its physical characteristic. The new supply relatively differs from the current stock and be an alternative particularly in dwelling size and quality of housing environment. However, accessibility to the new supply is limited to low-income groups particularly. Depending on the limited housing stock and the tight housing market, the competition among households in order to choose and allocate themselves to the best proper alternative would be competitive. The expectation of the choice structure would differ particularly in housing properties in the BND case is supported by equation results. Either the number or the impact of the housing properties and site-specific characteristics on the households' choice structure are remarkable than that the socio-economic characteristic of the households in all equations except for the low-income group. Among all the variables, the impact of the floor on the choice structure is the highest.

Results reflect that households tend to consume more dwelling space in two case areas. While the roomstress (spatial mismatch between actual and required housing) pushes households in the IMA, the floor area does in BND. These two variables are not identical; however both emphasize the size, therefore, interpreted as a tendency of consuming larger dwellings. The impact of roomstress among the other housing properties is striking in the IMA. In BND, households are more likely to choose houses larger in floor area. Floor is not included in the choice structure of the lower-income subgroup. The new supply is an alternative to provide relatively larger dwellings in size; however, the accessibility is limited to the low-income groups depending on market prices of housing. Consequently, its absence in the choice structure of the lower-income group is reasonable. In $\mathrm{BND}$, the higher income group tends to consume larger dwellings.

Results reflect that households exhibit unpredictable location preferences. Alonso (1974) and Muth (1969) emphasizes that households take into account regular journey to work, particularly lower-income households. It is emphasized that an increase in transportation cost is expected to reduce the real income of households and thus its consumption of housing services (Muth 1969). However, households are not responsive to commuting distances in two case areas. This may be 
a striking difference of these cases from the researched several Western cities (Kim et al. 2005; van Duijn, Rouwendal 2012; Bhat, Guo 2007; Follain, Jimenez 1985; Quigley 1985; Waddell 1993).

In the IMA, apart from comparable groups, side is clearly a valuable characteristic of a location. Households are more likely to choose houses located at European side, yet less likely to choose houses located at Asian side. The percentage distribution both in size and capacity of job areas, cultural and social facilities, schools; the current location of CBD; and the population shares of these geographical parts, European side provides more opportunities than the Asian side. Moreover, newly announced huge public investments such as the Third Airport and Canal Istanbul are located at the European side and they increase the competitive advantage of the side against to the Asian side. The market price of housing is determined by market conditions and the expected future value of the investment has an important role on the price determination as well. Therefore, the expected economic benefits of locating at the European side might make this side more attractive.

Housing choice structures of comparable income groups do not reflect remarkable differences in the IMA. However, tenure type impacts the choice structure. The percentage decrease in number of rooms or the percentage increase in roomstress is two important facts of the renters' choice structure. However, none of these variables has an impact on the homeowners' choice structure. This might reflect that being a homeowner is the main concern and homeowners abandon some properties in order to being a homeowner.

In BND, the housing choice structure of comparable groups reflects differences. The choice structure for lower-income groups is defined by socio-economic characteristics of the households. However, the impact of socio-economic characteristics is strikingly decreasing for higher income groups. It is determined by dwelling characteristics and the quality of housing environment basically. Consequently, the choice structure of lowerincome groups is limited; dwelling properties are abandoned by considering socio-economic characteristics. This might show the limits of choosing the single best unit and mobility across the existing housing stock for lower-income groups. Differing from the IMA, tenure structure does not make prominent difference in the choice structure in BND. The choice structures of both homeowners and renters are defined by the same socio-economic and dwelling characteristics. The basic difference is the responsiveness of homeowners to the housing environment. A negative percentage change in the safety has an impact on the choice structure of the homeowners.

\section{CONCLUDING REMARKS}

This investigation describes factors that define households' choice structures by examining two case areas. Both the economic and sociodemographic approaches are combined in order to model the households' housing choice structure in these case areas - the Istanbul Metropolitan Area (IMA) and Bandirma (BND).

Estimation results show that the socio-economic structure of households has the highest impact on the housing choice structure in the metropolitan area. Housing market structure provides several alternatives, consistently; households' would have high opportunities to tradeoffs that weaken the impact of the physical characteristics of housing in the choice structure.

In particular to the case area, the market potential to response the tradeoffs are limited in BND; competition to get the best proper alternative would be high. Consequently, either the number or the impact of the housing properties on the choice structure is high for the city as a whole and for comparable groups except the low-income group. The choice structure of the low-income group is defined by socio-economic characteristics. This might mean that housing market is quite tight for this particular group and depending on stock properties this group might be trapped in small niches. Some of the site specific characteristics such as the environmental quality based on safety and density is the factors of the choice structure. However, these characteristics are included in the homeowners' and high-income group's equations among comparable groups. Therefore, it might be said that considering environmental quality as a fact of choice structure goes parallel with well-being.

\section{ACKNOWLEDGEMENTS}

I would like to thank Istanbul Greater Municipality for providing the "Household Research" data. The BND data set is supplied by the ongoing research project entitled Considering the SocioEconomic Structure, Analyzing the Housing Market Structure in Alternative Ways and Modeling It , which is financially supported by the Istanbul Technical University Scientific Research Projects Support Center. 


\section{REFERENCES}

Alkay, E. 2008. Housing submarkets in Istanbul, International Real Estate Review 11(1): 113-127.

Alkay, E. 2011. The residential mobility pattern in the Istanbul metropolitan area, Housing Studies 26(4): 521-539. http://dx.doi.org/10.1080/02673037.2011.5 59752

Alonso, W. 1974. Location and land use: toward a general theory of land rent. Cambridge, Massachusetts: Harvard University Press.

Andersson, A. E.; Pettersson, L.; Strömquist, U. 2007. European metropolitan housing market. Springer. http://dx.doi.org/10.1007/978-3-540-70513-0

Balchin, P. N.; Isaac, D.; Chen, J. 2000. Urban economics a global perspective. $1^{\text {st }}$ edition. New York: Palgrave.

Bayoh, I.; Irwin, E. G.; Haab, T. 2006. Determinants of residential choice: how important are local public goods in attracting homeowners to central city locations, Journal of Regional Science 46(1): 97-120. http://dx.doi.org/10.1111/j.0022-4146.2006.00434.x

Berberoğlu, M. 2009. Mortgage - Ípotekli Konut Finansman - Sistemi ve Bu Sistemin Türkiye'de Uygulanabilirliği, International Journal of Economic and Administrative Studies 1(2): 119-146.

Bhat, C. R.; Guo, J. Y. 2007. A comprehensive analysis of built environment characteristics on household residential choice and auto ownership levels, Transportation Research Part B 41: 506-526. http://dx.doi. org/10.1016/j.trb.2005.12.005

Can, B. 2011. İpotekli Konut Finansmanına Yönelik Düzenlemeler ve Diğer Ülkelerle Mukayesesi, $T B B$ Dergisi, Sayı 97: 231-268.

Clapham, D. 2002. Housing pathways: a post modern analytical framework, Housing, Theory and Society 19(2): 57-68. http://dx.doi. org/10.1080/140360902760385565

Clark, W. A. V.; Dieleman, F. M. 1996. Households and housing, choice and outcomes in the housing market. Center for Urban Policy Research, Rutgers - The State University of New Jersey, New Jersey.

Clark, W. A. V.; Huang, Y. 2003. The life course and residential mobility in British housing markets, Environment and Planning A 35: 323-339. http://dx.doi. org/10.1068/a3542

Clark, W. A. V.; Ledwith, V. 2006. Mobility, housing stress, and neighborhood contexts: evidence from Los Angeles, Environment and Planning A 38: 10771093. http://dx.doi.org/10.1068/a37254

Clark, W. A. V.; Deurloo, M. C.; Dieleman, F.M. 1984. Housing consumption and residential mobility, Annals of the Association of American Geographers 74(1): 29-43. http://dx.doi.org/10.1111/j.1467-8306.1984. tb01432.x

Follain, J. R.; Jimenez, E. 1985. Estimating the demand for housing characteristics: a survey and critique, Regional Science and Urban Economics 15: 77-107. http://dx.doi.org/10.1016/0166-0462(85)90033-X

Friedrich, P.; Piesch, C. 2007. Housing markets and policies in the Munich metropolitan area, in Anders- son, A. E.; Petersson, L.; Strömquist, U. (Eds.). European metropolitan housing markets. Berlin: Springer, 85-120. http://dx.doi.org/10.1007/978-3-540-70513-0_4

GYODER (Gayrimenkul Yatırım Ortaklığı Derneği), İstanbul 2011. "Gayrimenkul Zirvesi”.

Hirsch, W. Z. 1968. The supply of urban public services, in Perloff, H. S.; Wingo, Jr. L. (Eds.). Issues in urban economics. The Johns Hopkins Press, USA, 477-525.

Huang, Y. 2004. Housing markets, government behaviors, and housing choice: a case study of three cities in China, Environment and Planning A 36: 45-68. http://dx.doi.org/10.1068/a35158

Kabataş, Y. 2007. Ipotekli Konut Finansman (Mortgage) Sistemindeki Riskler ve Mortgage Sigortası, Marmara Üniversitesi I.I. B.F Dergisi 22(1): 189-199.

Keskin, B. 2008. Hedonic analysis of price in the Istanbul housing market, International Journal of Strategic Property Management 12(2): 125-138. http:// dx.doi.org/10.3846/1648-715X.2008.12.125-138

Kim, J. H.; Pagliara, F.; Preston, J. 2005. The intention to move and residential location choice behaviour, Urban Studies 42(9): 1621-1636. http://dx.doi. org/10.1080/00420980500185611

Knox, P.; Pinch, S. 2006. Urban social geography. $5^{\text {th }}$ ed. Pearson-Prentice Hall, UK.

Koramaz, K.; Dökmeci, V. 2012. Spatial determinants of housing price values in Istanbul, European Planning Studies 20(7): 1221-1237. http://dx.doi.org/10.1080/0 9654313.2012.673569

Leishman, C. 2003. Real estate market research and analysis. $1^{\text {st }}$ ed. Houndmills: Palgrave-Macmillan.

Lowry, I. S. 1964. A model of metropolis, RM-4035-RC. The Rand Cooperation, Santa Monica, CA.

Maclennan, D. 2007. Recovery and change: Glasgow's housing 1991-2001, in Andersson, A. E.; Petersson, L.; Strömquist, U. (Eds.). European metropolitan housing markets. Berlin: Springer, 121-144. http:// dx.doi.org/10.1007/978-3-540-70513-0_5

Magalhaes, C. 2002. Global players and the re-shaping of local property markets: global pressures and local reactions, in Guy, S.; Henneberry, J. (Eds.). Development and developers, perspectives on property. Blackwell, UK, 224-246. http://dx.doi. org/10.1002/9780470757192.ch12

Megbolugbe, I. F.; Marks, A. P.; Schwartz, M. P. 1991. The economic theory of housing demand: a critical review, Journal of Real Estate Research 6(3): 381-393.

Muth, R. F. 1969. Cities and housing. The University of Chicago Press.

Onaka, J.; Clark, W. A. V. 1983. A disaggregate model of residential mobility and housing choice, Geographical Analysis 15(4): 287-304. http://dx.doi. org/10.1111/j.1538-4632.1983.tb00788.x

Pagliara, F.; Wilson, A. 2010. The state-of-the-art in building residential location models, in Pagliara, F.; Preston, J.; Simmonds, D. (Eds.). Residential location choice, models and applications. London: Springer, 1-21. http://dx.doi.org/10.1007/978-3-642-12788-5_1

Quigley, J. M. 1985. Consumer choice of dwelling, neighborhood and public services, Regional Science and Urban Economics 15: 41-63. 
Resmi Gazete. 2007. Kanun No. 5582, Konut Finansmanı Sistemine İlişkin Çeşitli Kanunlarda Değişiklik Yapılması Hakkında Kanun, Sayı: 26454, 6 Mart 2007.

Rossi, A. A. 2007. The housing market in Zurich's urban agglomeration, in Andersson, A. E.; Petersson, L.; Strömquist, U. (Eds.). European metropolitan housing markets. Berlin: Springer, 145-164. http://dx.doi. org/10.1007/978-3-540-70513-0_6

Rossi, P. H. 1955. Why families move: a study in the social psychology of urban residential mobility. New York: The Free Press.

Schnare, A.; Struyk, R. 1976. Segmentation in urban housing markets, Journal of Urban Economics 3: 146-166. http://dx.doi.org/10.1016/00941190(76)90050-4

Smith, L. B.; Rosen, K. T.; Fallis, G. 1988. Recent developments in economic models of housing markets, Journal of Economic Literature 26(1): 29-64.

Speare Jr., A.; Goldscheider, K. K. 1987. Effects of marital status change on residential mobility, Journal of Marriage and the Family 49(2): 455-464. http:// dx.doi.org/10.2307/352314

Tiebout, C. M. 1991. A pure theory of local expenditures (1956), in Cheshire, P. C.; Evans, A. W. (Eds.). Urban and regional economics. An Elgar Reference Collection, 513-523.

Tu, Y.; Goldfinch, J. 1996. A two-stage housing choice forecasting model, Urban Studies 33(3): 517-537. http://dx.doi.org/10.1080/00420989650011898

TUIK. 2010. Building permit statistics 2010. Turkish Statistical Institute.

TUIK. 2012. Haber Bülteni, Sayı: 10762, 05/06/2012. Turkish Statistical Institute.

Türkiye Müteahhitler Birliği. 2012. İnşaat Sektörü Analizi.

van Duijn, M.; Rouwendal, J. 2012. Analysis of household location behaviour, local amenities and house prices in a sorting framework, Journal of Property Research 29(4): 280-297. http://dx.doi.org/10.1080/09599916.2012.717100

Waddell, P. 1993. Exogenous workplace choice in residential location models: is the assumption valid?, Geographical Analysis 25(1): 65-82. http://dx.doi. org/10.1111/j.1538-4632.1993.tb00280.x

Wheaton, W. C. 1974. A bid rent approach to housing demand. WP 135, Massachusetts Institute of Technology, Cambridge. 